\title{
英国助成機関の大胆な挑戦
}

\section{Fixing a grant system in crisis}

Richard Van Noorden and Geoff Brumfiel 2010 年 3 月 25 日 Vol. 464 (474-475)

www.nature.com/news/2010/100324/full/464474a.html

英国工学・物理科学研究会議（EPSRC）の新しい厳罰主義が注目されている。

過去 2 年間、申請書 3 件が評価ランキングの下位半分に入り、

かつ全申請数の合格率が $25 \%$ 以下の研究者は、ブラックリストに載せられ、

1 年間、たった 1 件しか助成申請を出せなくなった。

1 月 21 日、ノッチンガム大学の物理学 者Philip Moriarty は、EPSRC (英国工学・ 物理科学研究会議) から恐るべき $\mathrm{E} メ ー$ ルを受け取った。彼は「複数不合格申請 者」に特定され、大学の研究担当者にも 通知されたのだ。EPSRCの新ルールは 4 月 1 日から完全実施され、Moriarty はいま「1年間の泠却期間」に追い込ま れている。この間、EPSRCに出せる申 請書は 1 件だけとなる。これまでは何 件でも提出できたのに、である。

EPSRC は物理分野で英国最大の研究 費助成機関。2009 2010 年の予算は 815 ポンド（1700 億円）に上る。新厳 罰制度の犠牲者は Moriarty を含む 140 人だけではない。「こんな馬鹿げた制度 を支持する人なんていませんよ」と同じ 大学の Amaria Patanè は怒りをぶちま ける。彼女はもっと悪い不合格者リスト 450 人の 1 人にリストアップされ、同じ く「1 年間の冷却期間」入りとなった。

EPSRC の新政策は、科学界にかかる 過剩負荷を緩和する対策の 1 つだ。助 成申請件数に対する合格率は、2000 年 の $43 \%$ から 2008 年の $26 \%$ まで落ちて いるし、毎年 5000 人の審査員（ピアレ ビューアー）を探さねばならない状況 もある。EPSRC はまた、一度不合格に なった申請書の再提出拒否も始めてい る。研究担当部長 Clive Hayter による と、この対策は功を奏しているようで、 申請数が昨年比で $35 \%$ も減った。
申請数が増え合格率が急落している のは世界共通だ。米国、ヨーロッパ、 アジアの助成機関は EPSRCの実験を、 固唾をのんで見守っている。彼らも同 じ悩みを抱えているからだ。NSF（全米 科学財団）の匿名担当者はこう打ち明 ける。「初めはやりすぎだとみていまし たが、今では、私たちも検討を始めて よいと考えています」。

「科学界の重荷を減らさなければなり ません。目的は、研究者の行動を変える ことなのです」と Hayter。変化を促す ため、EPSRC は 2009 年、次の 2 つの 条件を満たす研究者は 1 年間、申請を 禁止すると宣言した。(1)代表申請者と して出した 3 テーマ以上が、 2 年間のラ ンキングで下位半分に入っていること、 (2)全申請数の合格率が $25 \%$ 以下である

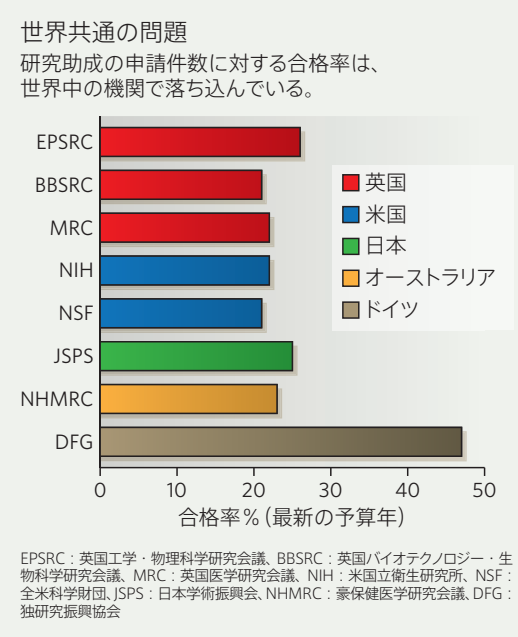

こと。この「三振、即退場」の方針は、 科学者の激しい抵抗に遭つた。その結 果、実施時期が延期され、年 1 件の申 請は許可するという緩い条件に変えて 実行されることになったわけだ（Nature 2009 年 5 月 7 日号 20 ページ)。山の ような申請が止まり、合格率が 30 〜 40\%に回復すれば「基準を緩和したい」 と Hayter はいう。

各国の助成機関も同様の課題に向き 合っている。NIH（メリーランド州ベセ スダ)では、2008 年の合格率は $22 \%$ だ た。日本学術振興会 (JSPS) の科研費 の合格率は $25 \%$ である。一方、ドイッ の主要助成機関である DFG は 47\%の合 格率を誇る。ただドイッの場合、資金の 多くが大学から直接支給されている。

問題に対処するため、これらの機関は 英国よりも平等主義的方策を採ってい る。例えば日本では、 1 件当たりの額を 減らして対応している。しかし、日本学 術会議の金澤一郎会長は「このような対 策は、申請書に約束した内容の実行可能 性を危うくする」と指摘する。

米国とドイツでは、既に申請書類を簡 略化する決定がなされている。書類が簡 潔になれば、担当者や審査員の負担が軽 減するからだ。DFG は 2 月、論文リス トを大胆に制限する方針を打ち出した (Nature 2010 年 2 月 25 日号 1009 ペー ジ)。しかし、簡略化は逆効果で、申請 数がどんどん増える危険性がある、と $\mathrm{NIH}$ 公開研究担当部長の Sally Rockey は指摘する。

EPSRCの厳しい新ルールに対して、 昨年みられたような激しい英国科学者の 抵抗は今のところ現れておらず、大半の 研究者は静観しているようにみえる。

しかし、何人かは既に新システムから の離脱を決めている。エリオット・ワッ ト大学 (英国エジンバラ) の化学物理学 者 Martin McCoustra もブラックリス ト入りとなった 1 人だが、彼は「EPSRC からの審査依頼は今後一切拒否する」と いっている。

(翻訳再構成：編集部) 